\title{
PEMAHAMAN KHUSUS TERHADAP PROFESIONALISME KEPEMIMPINAN GURU KRISTEN
}

\author{
Oleh : Pdt. Dr. Herman Krey, M.Pd.K \\ Dosen Pasca Sarjana STT Erikson - Tritt
}

\begin{abstract}
ABSTRAK
Dunia pendidikan memerlukan guru profesional. Pendidikan Kristen memerlukan Guru Kristen yang profesional. Dalam kamus Webster memberikan defenisi mengenai profesi yakni:

Profesi merupakan suatu pekerjaan yang menuntut pendidikan tinggi (kepada pengembannya) dalam liberal arts atau science, dan biasanya meliputi pekerjaan mental dan bukan manual, seperti mengajar, keinsinyuran, mengarang, dan sebagainya; terutama kedokteran, hukum dan teknologi. ${ }^{1}$

Kata Profesional, sendiri mengandung makna yang mengacu kepada sebutan tentang orang yang menyandang suatu profesi dan sebutan tentang penampilan seseorang dalam mewujudkan unjuk kerja sesuai dengan profesinya. Penyandangan dan penampilan "profesional" ini telah mendapat pengakuan, baik secara formal maupun informal. Pengakuan secara formal diberikan oleh suatu badan atau lembaga yang mempunyai kewenangan untuk itu, yaitu pemerintah dan atau organisasi profesi. Sedangkan secara informal pengakuan itu diberikan oleh masyarakat luas dan para pengguna jasa suatu profesi. Dengan demikian, profesional menunjuk pada dua hal. Pertama, orang yang menyandang suatu profesi, misalnya "Dia seorang profesional. "
\end{abstract}

${ }^{1}$ Webster's New World Dictionary, dikutip dari Saud, Profesi Guru, hlm. 3. 
Kedua, penampilan dari seseorang dalam melakukan pekerjaannya yang sesuai dengan profesinya. Pengertian kedua ini, profesional dikontraskan dengan "non-profesional" dan "amatir." Profesional adalah seseorang yang melakukan suatu (kegiatan, aktivitas, usaha, pekerjaan) yang dilakukan untuk mendapatkan (nafkah, kesenangan) atau memberi (konstribusi) dengan mengandalkan (keahlian, keterampilan, kemahiran) yang tinggi dengan melibatkan komitmen pribadi (moral) yang mendalam. ${ }^{2}$ Ditambahkan juga bahwa orang tersebut juga merupakan anggota suatu entitas atau organisasi yang didirikan sesuai dengan hukum di sebuah negara atau wilayah.

Guru profesional adalah seorang guru yang melakukan kegiatan, aktivitas dan pekerjaannya dengan mengandalkan keahlian, ketrampilan, kemahiran dengan komitmen yang tinggi. Guru Kristen yang profesional adalah guru Kristen yang bercermin dan belajar dari Yesus Kristus sebagai guru agung yang sudah tentu Ia adalah guru profesional. Kepemimpinan guru Kristen dikerjakan oleh guru Kristen yang profesional yang berarti bahwa pekerjaan guru secara profesional berarti juga melakukan kepemimpinan dalam pekerjaan tersebut.

\section{Kata Kunci : Profesionalisme, Kepemimpinan, Guru Kristen}

\section{A. PENDAHULUAN}

Kajian terhadap profesionalisme kepemimpinan guru kembali ditegaskan dalam bagian ini ialah hal-hal yang mencakup dalam konteks pendidikan atau keguruan. Tekanan utama penulis bukan pada konsep kepemimpinan Kristen secara umum, namun secara khusus kepemimpinan dalam pendidikan. Oleh sebab itu, penyajian penulis dalam bagian ini dan selanjutnya adalah hal-hal yang berkenaan dengan keguruan yang dilekatkan dengan adanya nilai kepemimpinan. Para guru Kristen harus mewaspadai adanya mitos kepemimpinan yang berkata bahwa seorang pemimpin tercipta saat dilahirkan - bahwa ada faktor genetik pada kepemimpinan. Mitos itu juga menegaskan bahwa 2009.

${ }^{2}$ Haryanto, http://www.haryantokandani.com/profesionalisme.php. 17 November 
manusia memiliki atau tidak memiliki sifat karismatik tertentu. Itu semua adalah mitos yang keliru dan sesungguhnya para pemimpin adalah dibentuk dan bukan dilahirkan (Warren G. Bennis). ${ }^{3}$ Oleh sebab itu, setiap pribadi memiliki potensi sebagai pemimpin, demikian juga para guru.

\section{Profesionalisme Kepemimpinan Guru Kristen}

Profesionalisme kepemimpinan guru Kristen adalah paket yang sesungguhnya melekat dalam panggilan keguruan. Namun sayangnya tidak semua guru Kristen menyadarinya, sehingga tidak banyak yang memaksimalkan potensi kepemimpinannya dalam proses belajarmengajar. Hal ini dapat menjadi salah satu indikator akan lemahnya komitmen guru dalam panggilannya, karena konsep/citra dirinya sebagai guru hanya dipahami sebagai pengajar semata.

Kepemimpinan guru Kristen adalah panggilan mulia yang diberikan Allah kepada orang percaya yang terpanggil sebagai guru, ${ }^{4}$ untuk memajukan komunitasnya dalam pencerahan intelektual dan iman yang tertuju kepada Yesus Kristus. Iman dan intelektual adalah misi yang diemban oleh guru Kristen. Konsep keseimbangan di antara keduanya adalah menjadi perjuangan berat guru Kristen. Ketidaksadaran akan panggilan ini membuat banyak guru Kristen yang menjalani panggilan keguruannya yang sama dengan guru lain yang tidak beriman kepada Yesus Kristus.

Kepemimpinan guru Kristen adalah anugerah yang diberikan Allah. Sesungguhnya tidak didapatkan seseorang karena kekuatan, kehebatan, kepintaran maupun kelayakannya, semuanya adalah bertumpu pada anugerah. Oleh sebab itu anugerah tersebut harus direspon dengan kasih kepada Allah dan mengembannya juga dengan konsep anugerah kepada orang lain. Itulah sebabnya mengapa kepemimpinan diktator yang tanpa kasih karunia tidak dikenal dalam kamus kepemimpinan Kristen. Anugerah yang diperoleh dengan proses pengorbanan yang mahal oleh Kristus. Orang percaya layak untuk menerima segala berkat, keselamatan dan hikmat memimpin adalah karena pengorbanan Kristus yang mendahului segalanya.

\footnotetext{
${ }^{3}$ Sonny Eli Zaluchu: http://glorianet.org/kolom/kolo_304.html. 17 November 2009.

${ }^{4}$ Rionta Sembiring. Diktat - Bahan Kuliah Profesi Keguruan PAK, 2006, hlm. 6.
} 
Dengan kesadaran akan mahalnya proses pemberian anugerah Allah, maka guru Kristen selaku pengemban kepemimpinan harus menjalaninya dengan sungguh-sungguh. Kepemimpinannya harus dikerjakan dengan maksimal, dengan orientasi pengabdian kepada Allah, kerinduan memuliakan Allah, dan sentiasa memberikan yang terbaik kepada Allah. Anugerah inilah yang memampukan para guru Kristen untuk memimpin dengan kasih, kejujuran, kesetiaan dan pengorbanan, atau dapat disingkat dengan memimpin dengan cara melayani. Nilai inilah yang disebut dengan profesionalisme kepemimpinan guru Kristen.

\section{Ciri-ciri Profesionalisme Kepemimpinan Guru Kristen}

Pencapaian pada titik profesionalisme kepemimpinan guru Kristen memang belum dimiliki oleh semua guru Kristen. Namun kendati demikian, idealnya sebagai pribadi tebusan dengan darah Kristus yang mahal, semua guru Kristen seharusnya hidup di alam profesional. Kendati dalam proses, namun harus tetap dalam perjuangan yang tinggi untuk mewujudkannya. Terlepas dari berbagai kendala dan tantangan yang relatif berbeda dan beragam, perjuangan untuk menjadi guru profesional haruslah berada dalam denyut jantung para guru Kristen. Adapun dua faktor utama yang menandakan ciri profesionalisme kepemimpinan guru Kristen ialah identitas pribadi dan kompetensi peran.

\section{a. Identitas Guru Kristen}

Istilah guru Kristen dapat dipahami dari tiga segi: Pertama, guru dalam perspektif Kristen; kedua, guru yang Kristen; ketiga, guru yang hanya memberi pengajaran yang berkaitan dengan iman Kristen. ${ }^{5}$ Arti yang pertama ialah menyangkut pembahasan yang umum tentang guru serta seluk-beluk keguruan dari sudut pandang iman Kristen. Arti yang kedua ialah lebih berkaitan dengan identitas atau jati diri serta peranan guru sebagai orang Kristen. Dalam artian yang ketiga memberi kesan

${ }^{5}$ B. S. Sidjabat, Menjadi Guru Profesional - Sebuah Perspektif Kristiani (Bandung: Kalam Hidup, 2000), hlm. 35. 
yang lebih sempit tentang lingkup tugasnya. Berbicara mengenai guru Kristen, maka ada dua hal yang penting yang menjadi perhatian utama.

Pertama ialah, mengenai kedudukan guru sebagai pribadi Kristen. Bagaimana ia sepatutnya memahami dan mengembangkan statusnya sebagai orang Kristen. Kedua, mengenai tugasnya sebagai pendidik dan pengajar. Apakah perannya sebagai guru dalam melaksanakan tugas keguruan? Bagaimana ia sepatutnya mengemban tugasnya sebagai guru berdasarkan iman kristiani yang dianutnya? Perenungan akan pertanyaan di atas akan mampu membawa guru pada citra profesionalisme kepemimpinannya.

Adapun hal-hal yang harus diperhatikan sehubungan dengan identitas guru Kristen ialah, pertama, bertumbuh dalam Kristus. Perkara yang sangat penting dikembangkan oleh seorang guru Kristen adalah pengenalan mengenai jati dirinya sendiri sebagai orang Kristen. Orang Kristen yang sejati adalah orang yang memberikan dirinya secara penuh kepada Yesus Kristus (bndk. Kis. 11:26). Orang Kristen adalah orang yang percaya dan menyambut sepenuhnya kedudukan dan peranan Yesus sebagai Tuhan, Juru selamat dan Raja atas kehidupannya. Pembukaan diri ini sebenarnya dimungkinkan oleh kuasa Allah sendiri, melalui pekerjaan Roh Kudus yang membuat seseorang memberi respon positif terhadap berita Injil. Dengan membuka diri, Roh Kudus berkenan hadir ke dalam hidup dan mendiami diri orang percaya. Dengan demikian nyatalah permulaan orientasi hidup baru, perubahan hidup, kualitas rohani baru, kuasa, dan dinamika hidup baru (Yoh. 3:3,5 Rm. 8:9-11; 2 Kor. 3:17, 18; 5:17). ${ }^{6}$

Selanjutnya, sebagai orang Kristen guru terpanggil untuk bertumbuh ke arah pengenalan yang semakin mendalam dan lengkap tentang pribadi Yesus Kristus. Pengenalan tentang pribadi Yesus Kristus akan memungkinkan guru untuk lebih memahami kehendak Allah. Karena Yesus sendiri adalah Jalan, Kebenaran dan Hidup. Sebab Yesus dengan tegas mengatakan bahwa di luar Dia, tidak seorangpun dapat melakukan hal yang benar bagi kemuliaan Allah (Yoh. $15: 4,5,16)$. Di samping itu, hanya melalui persekutuan dengan Dialah seorang guru Kristen semakin mampu menemukan kebenaran yang sesungguhnya. Dan kebenaran yang dinyatakan Allah kepada manusia menyangkut segi kognitif (intelek - pemikiran), segi moral, etis serta spiritual. Selanjutnya, kebenaran yang harus dikejar oleh guru Kristen

${ }^{6}$ Sidjabat, Menjadi Guru Profesional, hlm. 37. 
adalah kebenaran yang realistis, yaitu yang nyata dalam kehidupan sebagaimana dinyatakan dalam terang Firman Allah.

Seorang guru Kristen juga perlu menyadari bahwa peranan Roh Kudus bukan hanya berlangsung dalam rangka pendewasaan iman dan peningkatan kualitas atau kesadaran akan kesucian hidup, tetapi juga dalam rangka mengemban profesi sehari-hari yakni dalam seluruh aspek kehidupan. Roh Kudus ingin menyatakan kuasa dan kehadiranNya di dalam diri dan melalui orang percaya yakni pribadi guru Kristen tersebut. Karena itulah, guru bidang studi apapun, tetap memerlukan Roh Kudus dalam hidup dan pekerjaannya. Ia harus menyerahkan dirinya sepenuhnya kepada Allah. ${ }^{7}$ Roh Kudus juga menyatakan sifatNya melalui gerak-gerik dan gaya mengajar dari guru. Ia juga akan memberikan ide-ide baru dalam persiapan dan ketika mengajar. Ia memberikan semangat dan antusiasme. Ia mampu meyakinkan dan menyadarkan para pendengar. Ia membuat interaksi di antara sesama pelajar dan guru berjalan dinamis sehingga terasa hangat dan bermakna. Itulah sebabnya, guru Kristen harus selalu dipimpin dan dipenuhi oleh Roh Kudus. Selanjutnya, Sifat-sifat yang dipancarkannya itu dapat menjadi dinamika hidup dalam hubungan antar pribadi yang menyegarkan dan membangun. Sifat-sifat itu pulalah yang diharapkan mewarnai dan membentuk etos kerja seorang guru sebagai pengajar dan pendidik.

Kedua, citra diri positif. Seorang guru dengan konsep diri yang baik akan mampu memandang dirinya dimiliki atau diterima Allah tanpa syarat, sebab ia yakin bahwa darah Yesus Kristus yang telah tercurah di kayu salib merupakan bukti kuat akan kasih Allah terhadap dirinya (band. Rm. 5:6,8; Ibr. 9:14). Dengan melihat pada kasih Allah, maka penghargaan terhadap dirinya sendiri tidak didasarkan atas faktor fisik, materi dan prestasi. Allah menghendaki agar setiap guru Kristen menyadari bahwa mereka memandang diri mereka berharga karena mereka telah ditebus di dalam kasih Kristus serta dipanggil menjadi rekan sekerja-Nya. Dengan konsep dasar positif seperti inilah guru dapat memiliki perasaan mampu dan dimampukan oleh kuasa serta kehadiran Allah. Dengan begitu pula, guru dapat bebas dari rasa kurang percaya diri.

Adapun dampak dari pencitraan diri yang positif oleh guru mengenai dirinya ialah:

${ }^{7}$ Sembiring, Profesi Keguruan PAK, hlm. 6. 
Pertama, guru dapat berkembang secara sehat dalam relasi dengan orang lain, termasuk anak didik dan rekan sekerjanya. Ia mampu menerima orang lain sebagaimana adanya, sebab ia sadar bahwa pribadinya juga memiliki kelebihan dan kekurangan. Kemampuan semacam ini sangat diperlukan guru, mengingat guru menghadapi anak didik yang berasal dari berbagai kalangan dengan konsep diri yang kurang benar. ${ }^{8}$ Hal ini menolong guru dapat menerima dan menghargai anak didiknya sebagaimana mereka adanya.

Kedua, dengan konsep diri yang baik guru dapat bertumbuh dalam penerimaan akan dirinya, akan potensi-potensi positif dan negatif. Ia akan berupaya bertumbuh dalam segi-segi positif dan berusaha memerangi dimensi-dimensi yang negatif dalam dirinya. Dengan kata lain, ia mengembangkan persepsi diri yang sehat, dan tidak dilanda oleh prasangka negatif (Rm. 12:3,16; Flp. 4:8). Sebab prasangka buruk terhadap anak didik dan rekan kerja selalu menimbulkan gangguan bagi kesuksesan mengajar.

Ketiga, dengan citra diri positif guru dapat mengembangkan dirinya dalam segi berkorban demi orang lain, serta menempatkan kepentingan orang lain lebih dahulu. Sikap rela berkorban demi kemajuan anak didik sangatlah penting dimiliki oleh seorang guru. Dengan sikap mental demikian, maka guru tidak akan memaksakan kehendaknya. Seorang guru Kristen dapat melihat pribadi demikian pada Yesus Kristus, di mana Ia telah mengorbankan hidupNya demi keselamatan orang banyak. Ia berkata bahwa tidak salah menjadi besar dan terkemuka di hadapan orang lain, tetapi cara yang tepat untuk sampai ke tujuan itu haruslah dengan menjadikan diri sebagai pelayan atau hamba bagi orang lain (Mat. 20:26-28). Prinsip ini jelas mengedepankan spirit pengorbanan.

Keempat, dengan konsep diri yang sehat, seorang guru akan mampu mengembangkan kemampuan dan ketrampilan pelayanannya dengan sikap percaya diri. Ia akan siap berperkara dalam segala hal bersama dengan Yesus Kristus yang memberikan kekuatan kepadanya (Flp. 4:13). Artinya, persekutuan hidup dengan Kristus dapat membuahkan kemampuan baru dalam pribadi seorang guru. ${ }^{9}$ Kemampuan memang tidak datang begitu saja tanpa upaya belajar dan latihan untuk meningkatkan diri. Namun harus diingat juga bahwa

${ }^{8}$ Sidjabat, Menjadi Guru Profesional, hlm. 38.

${ }^{9}$ Sidjabat, Menjadi Guru Profesional, hlm. 38. 
kemampuan tidak saja menyangkut segi ketrampilan berbuat, tetapi juga segi pemikiran dan perasaan. Kemampuan dan percaya diri inilah yang akan semakin dinyatakan Yesus di dalam diri seorang guru yang sepenuhnya bersandar kepada-Nya.

\section{b. Kompetensi Peran}

Dalam mewujudkan profesionalisme kepemimpinan guru Kristen, dibutuhkan tidak hanya identitas pribadi, tetapi juga kompetensi perannya yang dapat mencakup beberapa aspek. Sidjabat menguraikan setidaknya terdapat tujuh peran guru berkenaan dengan profesionalisme, ${ }^{10}$ yaitu:

Pertama, sebagai seorang ahli. Nilai yang terkandung dalam profesionalisme kepemimpinan guru ialah ia mengetahui tentang "apa" dan "bagaimana" dari bahan yang diajarnya. Itulah seorang guru harus terus belajar meningkatkan pengetahuannya. Ia memang dituntut untuk menjadi ahli, setidaknya pada bidang yang dikuasainya. ${ }^{11}$ Ia tidak hanya mampu menjelaskan banyak tentang bahan yang diajarkannya, tetapi juga dapat membantu anak didiknya mengenal strategi praktis bagi penguasaan bahan ajarannya. Dengan kata lain, tugas guru adalah membantu anak didiknya untuk memahami bagaimana cara mendalami dan menguasai pelajaran yang akan atau sedang dipelajarinya. Oleh sebab itu guru harus memiliki model atau gaya belajar tersendiri terhadap anak didiknya yang jelas berbeda satu dengan lainnya. Inilah yang disebut dengan keahlian guru.

Kedua, sebagai seorang motivator. Tugas ini adalah hal yang sangat penting. Sebagai seorang guru, ia tentu memimpin para muridnya. Agar para muridnya dapat mengikuti pelajaran dengan semangat, maka ia harus mampu memberikan motivasi belajar yang baik. Hal ini sangat penting, mengingat peristiwa belajar pada dasarnya berlangsung dalam diri anak didik. Hal ini berarti, bahwa para murid merupakan pelaku proses belajar bagi dirinya sendiri. Guru tidak dapat belajar bagi anak didiknya. Yang dapat dikerjakan guru ialah memberikan rangsangan, membangkitkan semangat dan perasaan mampu dalam diri anak didik, yang selanjutnya diharapkan sanggup menggerakkan minatnya dalam melakukan perbuatan belajar. Oleh

${ }^{10}$ Ibid.

${ }^{11}$ Serrano, Profesionalisme Guru dan Bingkai Materi, hlm. 33. 
sebab itu, guru harus menunjukkan antusiasme terhadap para murid dan pelajaran yang disampaikannya, serta mendemontrasikan itikad baik untuk membina relasi yang membangun anak didiknya.

Ketiga, sebagai fasilitator. Dalam hal ini berarti guru terpanggil untuk memahami kebutuhan atau keperluan anak didik dalam proses belajar. Sebagai fasilitator, guru mempersiapkan berbagai sarana dan prasarana yang menunjang kegiatan belajar-mengajar. Ia menyediakan alat bantu pendengaran, menyediakan literatur yang relevan, menciptakan kondisi emosional dan sosial yang bermanfaat bagi peristiwa belajar. Ia juga menyediakan waktunya untuk konsultasikonsultasi pribadi baik di dalam maupun di luar ruangan kelas. Namun semuanya harus dalam kerangka konteks memajukan para anak didik, tidak dimuati dengan berbagai motif lainnya.

Keempat, sebagai komentator/ evaluator. Tugas guru dalam peran ini ialah memberi penilaian terhadap kemajuan anak didik. Guru juga harus menyampaikan informasi yang berguna untuk kemajuan. Dalam menjalankan perannya ini, guru harus selalu menjadi dirinya untuk tetap dapat menyampaikan kritikan dan informasi secara tepat dan jujur di waktu yang tepat. Ia harus mengembangkan kemampuannya dalam mengemukakan pandangan yang bersifat membangun semangat. ${ }^{12}$ Jika tidak, para anak didik akan menyimpan akar pahit ataupun kekesalan dalam dirinya akibat ketidaktepatan penyampaian kritikan atau evaluasi. Sebagai komentataor, guru harus mengembangkan dirinya agar mampu melihat secara objektif kekurangan dan kelebihan anak didiknya. Ia juga harus terus-menerus belajar membedakan antara kekurangan pribadi atau kekurangan karya/hasil kerja, berkaitan dengan pendapat/ide atau pekerjaan. Kemampuan menilai dan membedakan hal tersebut dengan objektif akan tertransfer kepada anak didik dalam hal cara mereka menilai suatu hal.

Kelima, sebagai komunikator. Sebagai komunikator, guru banyak memainkan peran sebagai perantara (mediator). Ia diharapkan menjadi mediator di antara anak didik dengan bahan pengajaran dan di antara sesama anak didik. Maka sebagai komunikator, guru memainkan peranan penting baik dalam proses pemahaman materi, maupun interaksi kelas. Komunikator yang baik selalu mengutamakan berita

${ }^{12}$ Asep Jihat \& Abdul Haris, Evaluasi Pembelajaran (Yogyakarta: Multi Pressindo, 2008), hlm. 28. 
dari segi kebutuhan pendengarnya. ${ }^{13}$ Maka guru harus menyampaikan pengajaran yang sesuai dengan kebutuhan anak didiknya. Ia dengan cermat harus mengetahui di mana anak didiknya berada, secara rohani, intelek, moral, di samping secara fisik. Sebagai komunikator, guru juga harus menggunakan kata-kata yang jelas, tepat sesuai dengan pengertian anak didik.

Keenam, guru sebagai agen sosialisasi. Dalam peran ini, guru berupaya membantu anak didik mengalami interaksi edukatif, saling mengenal dan saling mengisi melalui diskusi dan kerja kelompok. Dengan menyadari bahwa anak didik adalah makhluk individu dan makhluk sosial, maka cara belajar juga harus menempuh dua pendekatan ini, yaitu pendekatan pribadi dan pendekatan sosial. Untuk mencapai itu, guru perlu mengembangkan pemberian rangsangan seperti pujian, penghargaan atau kemajuan dan kebaikan setiap anak didik serta menolong terjadinya kompetisi yang sehat di antara anak didik. Maka pada akhirnya, akan terbentuk atmosfir sosial yang kondusif dalam proses belajar-mengajar.

Ketujuh, sebagai pelajar. Guru yang tidak sadar bahwa pengetahuan berkembang, dan bahwa anak didik yang dihadapinya berubah-ubah, akan mengalami ketertinggalan. Oleh sebab itu, guru perlu tampil dengan kesegaran baru, segar dalam pengetahuan, kerohanian dan bahkan secara fisik. Karena itulah guru terpanggil untuk terus mengembangkan dirinya, wawasan, dan kreatifitasnya. Langkah utama untuk mewujudkan itu adalah dengan terus belajar.

\section{Tujuan Profesionalisme Kepemimpinan Guru Kristen}

Pergumulan dalam dunia kepemimpinan memang akhir-akhir ini selalu diwarnai dengan kesan yang negatif. Dalam beberapa tempat dan bagian, memang kerap terjadi penyimpangan posisi kepemimpinan, tidak terkecuali dalam kehidupan gereja. Oleh sebab itu, dalam bagian ini perlu ditegaskan bahwa tujuan daripada profesionalisme kepemimpinan guru Kristen tidak untuk mencari popularitas atau kuasa untuk bertindak sewenang-wenang. Panggilan kepemimpinan dalam kehidupan orang percaya sesungguhnya tidak memiliki motif pribadi tetapi pengabdian kepada Sang Pemanggil.

\footnotetext{
${ }^{13}$ Sidjabat, Menjadi Guru Profesional, hlm. 43-44.
} 
Dalam konteks kependidikan, kepemimpinan guru Kristen bertujuan untuk mengelola terjadinya proses belajar-mengajar yang baik. Seluruh potensi kepemimpinan dan daya gunanya adalah untuk memajukan anak didik dan membangun rekan guru. Dengan demikian, kendati memiliki otoritas, namun tidak boleh berlaku secara otoritatif. Ia selalu mencari upaya agar menjadi bagian dari kehidupan anak didik sehingga mereka dapat melihat dari dekat seluk-beluk kehidupannya. Ia berani hadir dalam kehidupan para anak didiknya, karena ia telah menjadikan dirinya sebagai surat Kristus yang dapat dibaca oleh setiap orang khususnya para anak didik (2 Kor. 3:2-3). Dengan kehadirannya, maka ia memberi pengawasan (berdiri di belakang) bagi kemajuan belajar yang hendak dicapai anak didik.

Tiga faktor utama yang diemban dalam pengabdian profesionalisme kepemimpinan guru Kristen ialah pembangunan relasi (sesama guru dan anak didik), pencapaian tujuan dan transformasi/ perubahan hidup. Kedua hal pertama yaitu pembangunan relasi dan pencapaian tujuan haruslah diupayakan secara seimbang. ${ }^{14}$ Ketimpangan pada salah satu menimbulkan kecacatan dalam kepemimpinan yang berdampak langsung pada kemajuan anak didik dan sekolah. Pengutamaan pada relasi dapat membuat guru enggan melakukan disiplin secara tegas terhadap anak didik ketika terjadi halhal yang kurang membangun. Demikian juga ketika terjadi pada sesama guru, mereka akan sungkan untuk menegur kesalahan atau kelalaian yang diperbuat guru lain. Namun pengutamaan pada tujuan membawa guru pada sikap yang kaku dan suasana yang dingin. Pada akhirnya guru yang demikian akan terkesan otoritatif. Sebagai pemimpin yang baik, guru harus menekankan pencapaian keduanya secara seimbang. Untuk menegakkan keseimbangan tersebut guru sebaiknya bersikap demokratis, mau berdiskusi guna mencari langkahlangkah terbaik demi kepentingan bersama.

Pada pencapain faktor yang ketiga dituntut adanya pengaruh langsung dari guru. Guru membawa pengaruh untuk menghasilkan perubahan di dalam diri orang lain. Seorang guru yang mengemban kepemimpinannya akan disebut sebagai pemimpin jika kehadirannya membawa perubahan positif bagi orang-orang disekitarnya. Perubahan nilai di dalam diri orang-orang (yang terkena pengaruh tersebut) akan membentuk sebuah sistem nilai yang juga baru di lingkungan di mana

${ }^{14}$ Sidjabat, Menjadi Guru Profesional, hlm. 42. 
orang-orang itu berada. Fokus utamanya adalah pembentukan nilainilai di dalam diri orang lain, sehingga terbentuk sebuah karakter dan kebiasaan (habits) yang bagus dan luar biasa, yang mencerminkan Kristus.

\section{Strategi Membangun Profesionalisme Kepemimpinan Guru Kristen}

Guru Kristen dalam mengembangkan profesionalisme kepemimpinannya dalam mengajar sepenuhnya harus meneladani Yesus Kristus. Kendati banyak acuan dan fasilitas yang tersedia, namun esensi kepemimpinan sejati guru Kristen hanya dapat ditemukan dalam pribadi Yesus Kristus. Dalam menjalankan amanah panggilannya sebagai guru yang memimpin, ia harus bertitik tolak pada pribadi Yesus sebagai guru yang harus diteladaninya dalam kehidupan sehari-hari dan dalam pelaksanaan tugasnya. Howard G. Hendricks, mengemukakan bahwa sedikitnya ada enam segi kehidupan Yesus yang senantiasa mengagumkan yang harus diteladani oleh guru Kristen, dalam mengemban misi kepemimpinan dalam pengajarannya, yaitu:

Pertama, dalam segi kepribadian. Yesus memperlihatkan kesesuaian antara ucapan dan perbuatan. Ia juga menuntut kesesuaian itu terjadi dalam diri para murid dan pengikut-Nya. Pemimpin yang mengajar haruslah memiliki kesesuaian ucapan dengan tindakan, agar anak didik mendengar dan mengikuti arahannya. Kedua, dalam segi pengajaran. Pengajararan-Nya lebih sederhana, realistis, dan tidak mengambang. Sederhana dalam arti menyinggung perkara hidup sehari-hari. Hal ini menuntut seorang pemimpin untuk mengetahui apa yang menjadi pergumulan real dalam kehidupan keseharian para anak didiknya. Ketiga, dalam segi Relasional. Yesus sangatlah bersifat relasional. Di mana ia selalu memperhatikan hubungan antar pribadi agar senantiasa harmonis. Pemimpin dalam konteks apapun tidak boleh mengabaikan prinsip ini. Keempat, Isi berita-Nya bersumber dari Allah yang mengutus-Nya. Selain relevan bagi pendengarnya, ajaran Yesus bersifat otoritatif dan efektif (Mat. 7:28-29). Kepemimpinan guru Kristen juga harus menyampaikan kebenaran yang bersumber dari Allah semata. Kelima, motivasi kerja-Nya adalah kasih. Ia menerima orang sebagaimana adanya, serta mendorong mereka untuk berserah kepada Allah. Kasih sebagaimana yang telah diteladankan oleh Yesus 
adalah ciri utama kepemimpinan Kristen. Keenam, metode-Nya bervariasi dan sangat kreatif. Ia bercerita dan bertanya. Ia melibatkan orang untuk memikirkan masalah yang diajukan-Nya. Selain hal tersebut, Ia mengenal orang yang dilayani-Nya, keadaan serta tingkat kerohanian mereka. ${ }^{15}$

Dengan mempelajari dan mengembangkan enam prinsip di atas, maka profesionalisme kepemimpinan guru Kristen akan segera terbangun dan berkembang. Dan jika prinsip-prinsip tersebut dapat dipertahankan, maka kepemimpinannya (dalam konteks pendidikan/ pengajaran) akan terus bertahan.

\section{B. KESIMPULAN}

Profesionalisme Kepemimpinan guru Kristen haruslah menjadi sebuah kehidupan yang dipersembahkan kepada Allah. Pelayanan guru sebagai pemimpin yang profesional memiliki nilai yang amat besar dan pastinya memberi dampak positif kepada anak didik. Oleh sebab itu menjadi sebuah keharusan bagi setiap guru Kristen untuk memberi dirinya sebagai guru yang melayani, melakukan pekerjaan mengajar yang berkualitas dan itu semua diperoleh dari contoh guru agung yaitu Yesus Kristus.

\footnotetext{
${ }^{15}$ Howard G. Hendricks, "Follow the Master Teaching," dalam Kenneth O. Gangel dan Howard G. Hendricks The Christian Educator's Handbook on Teaching (Wheaton Il. SP Publication, Victor Books, 1988), hlm. 13-29.
} 


\section{DAFTAR PUSTAKA}

\section{Buku-buku}

Asep, Jihat \& Abdul Haris. Evaluasi Pembelajaran. Yogyakarta: Multi Pressindo, 2008.

Hasugian, Johanes Waldes. Menjadi Guru PAK Profesional Melalui Supervisi Pendidikan Agama Kristen. 2nd ed. Medan: CV. Mitra, 2016.

Hasugian, Johanes Waldes. Strategi Belajar Mengajar Pendidikan Agama Kristen Yang Efektif. Prodi Teologi STT-SU, 2016.

Howard, G. Hendricks, "Follow the Master Teaching." Dalam Kenneth O. Gangel dan Howard G. Hendricks The Christian Educator's Handbook on Teaching. Wheaton Il: SP Publication, Victor Books, 1988.

Sidjabat, B.S. Menjadi Guru Profesional - Sebuah Perspektif Kristiani. Bandung: Kalam Hidup, 2000.

Non-Serrano, Janse Belandina. Profesionalisme Guru dan Bingkai Materi. Bandung: Bina Media Informasi, 2005.

Haryanto, http://www.haryantokandani.com/profesionalisme.php. 17 November 2009.

Sonny Eli Zaluchu: http://glorianet.org/kolom/kolo_304.html. 17 November 2009 